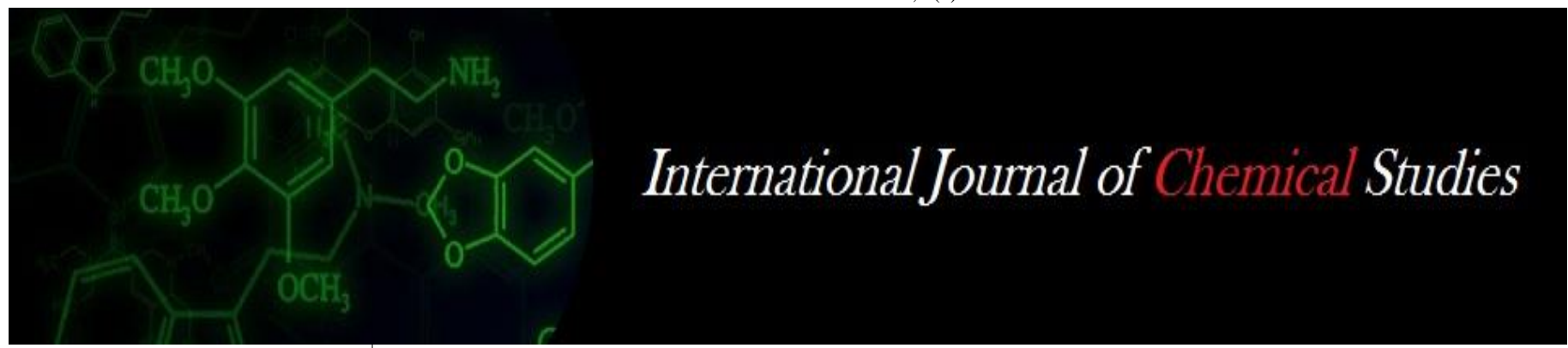

P-ISSN: 2349-8528

E-ISSN: 2321-4902

www.chemijournal.com

IJCS 2020; 8(4): 2282-2285

(C) 2020 IJCS

Received: 10-05-2020

Accepted: 12-06-2020

Ashoka P

Senior Scientist and Head,

ICAR- KVK, Ranebennur

Taluk, Haveri, Karnataka, India

Rajakumar GR

Scientist (Soil Science) ICAR-

KVK, Ranebennur Taluk,

Haveri, Karnataka, India

Priya $\mathbf{P}$

Scientist (Soil Science) ICAR-

KVK, Ranebennur Taluk,

Haveri, Karnataka, India
Corresponding Author:

Ashoka P

Senior Scientist and Head,

ICAR- KVK, Ranebennur taluk,

Haveri, Karnataka, India

\section{Response of soil and foliar application of nutrients on yield and nutrient uptake of foxtail millet (Seteria italic L.)}

\author{
Ashoka P, Rajakumar GR and Priya P
}

DOI: https://doi.org/10.22271/chemi.2020.v8.i4z.9972

\section{Abstract}

A field experiment was conducted during kharif -2018 and 2019 at ICAR- Krishi Vigyan Kendra, Haveri (Hanumanamatti) to study the response of foxtail millet (Seteria italic L) to soil application of micronutrients and foliar application of NPK along with RDF. The experiment was laid out in RCBD comprising of nine treatments replicated thrice. Studies revealed that the yield attributes and grain yield of foxtail millet differed significantly due to foliar application of NPK along with RDF and soil application of micronutrients along with RDF. The results indicated that significantly higher grain yield $\left(18.49 \mathrm{q} \mathrm{ha}^{-1}\right)$ and straw yield $\left(36.14 \mathrm{q} \mathrm{ha}^{-1}\right)$ of foxtail millet were recorded in treatment applied with RDF + foliar spray of 19:19:19 @ 1\% at flower initiation stage (pooled data of 2 years) followed by soil application of micronutrients along with RDF. The treatment RDF + foliar spray of 19:19:19 @ 1\% at flower initiation stage recorded significantly panicle length $(22.27 \mathrm{~cm})$ and grain weight per panicle $(2.80$ g). The biological yield, nutrient uptake (NPK, $\mathrm{Zn}$ and $\mathrm{Fe}$ ) are also significantly higher with the same treatment.

Keywords: Foxtail millet, nutrients nutrient uptake and yield

\section{Introduction}

The increasing cost of fertilizer nutrients have led to search for alternative practices of managing the fertilizer nutrients more judiciously, efficiently and in balance proportions. Such approach would reduce the depletion of macro and micronutrients from soil. Among the nutrients, macro-nutrients have been given the priority and little attention has been given the priority and little attention has been paid towards micronutrients. In the absence of micronutrients, plant shows physiological disorder which eventually lead to low crop yield and fair quality. Foliar spraying is a new method for crop feeding in which micronutrients in the form of liquid are used into levels. It has been found that micronutrient foliar application is in the same level and even more influential as compared to soil application (Fouly, 2010) ${ }^{[1]}$. Millets are small seeded cereals that are often termed nutri-cereals or dryland cereals found to be domesticated around 8000 years ago in the highlands of central China (Amgai et al., 2011) ${ }^{[2]}$. They comprise of different types like finger millet, foxtail millet, proso millet, pearl millet including sorghum which are well considered as the crops of antiquity mainly known for their drought resistance, insects, pests and disease resistance (Devi et al. 2014) ${ }^{[3]}$. Foxtail millet (Setaria italica (L.) Beauv.) is thought to be indigenous to southern Asia and is considered one of the oldest cultivated millets. In India, the cultivation of foxtail millet is confined to Karnataka, Andhra Pradesh, and Tamil Nadu. Foxtail millet comes under drought tolerant crop and it can be grown as a short-term catch crop. It is grown mainly in dry lands. It's grain used for human consumption and a feed for poultry and cage birds. It is used in several food preparations, like, chapati, fermented bread, biscuits, malts, etc. the stalks are used as fodder and for thatching. It is rich in micronutrients and good for diabetic patients. It protects against cancer and related heart diseases (Devi, et al. 2014) ${ }^{[3]}$. Foxtail millet is getting popular and its importance is realized now-a-days, because of its low requirement of inputs, wider adaptability and nutritional superiority over other cereals.

Soil fertility is one of the main limiting factors that influence production of crops. Introduction of high yielding hybrids and varieties in many crops, increased use of high analysis chemical fertilizers without adequate application of organics and micronutrients have resulted in wide 
spread deficiency of micronutrients and nutrient imbalance which adversely affected the yield of many crops. Zinc is an essential micronutrient for the growth and development of plants, humans and animals. Zinc deficiency in soil is affecting human health also. The growth and immune system of humans can be impaired by Zn deficiency. Zinc deficiency in soils may reduce yield and quality of the crop. Agronomic and genetic bio-fortification has been suggested as strategies to increase the dietary $\mathrm{Zn}$ through edible crops (Bouis and Welch, 2010) ${ }^{[4]}$. Although cereals and millets generally less sensitive to nutrient deficiency than pulses, still it affects the cereals by a deficiency in several parts of the world. In Karnataka, in few districts, millets are one of the main components of cropping system. Integration of organic and inorganic sources of nutrients play a pivotal role in enhancing crop productivity, sustaining soil health and reduce environmental hazard. Considering these, attempts were made to study the crop nutrition through foliar application of chemical fertilizers at flower initiation stage (45 DAS) of foxatil millet crop.

\section{Materials and Methods}

The experiment was carried out at Haveri (Hanumanamatti) ICAR-KVK of UAS, Dharwad (Karnataka) during Kharif season, 2018-19 and 2019-20, which is located at 25 $45^{\prime} 94^{\prime \prime}$ $\mathrm{N}$ latitude and $81^{\circ} 85^{\prime} 35^{\prime \prime} \mathrm{E}$ longitude of 980 meter above mean sea level (MSL). The field of experiment conducted is red sandy loam. The soil $\mathrm{pH}$ is 6.56 , organic $\mathrm{C}$ is 0.42 percent, Available N, P, K are 220, 16.25 and $162.5 \mathrm{~kg} \mathrm{ha}^{-1}$, respectively. The field experiment with Foxtail millet variety DHFt-109 having duration of 90-110 days was conducted in randomized block design with nine treatments $\left(\mathrm{T}_{1}\right.$-Control $, \mathrm{T}_{2}-\mathrm{RDF}, \mathrm{T}_{3}-\mathrm{RDF}+$ foliar spray of Urea @ $2 \%$ at flower initiation stage, $\mathrm{T}_{4}-\mathrm{RDF}+$ foliar spray of 19:19:19 @1\% at flower initiation stage, $\mathrm{T}_{5}$-Foliar spray of Urea @2\% flower initiation stage, $\mathrm{T}_{6}$-Only Foliar spray of 19:19:19@1\% at flower initiation stage, $\mathrm{T}_{7}-\mathrm{RDF}+\mathrm{ZnSO}_{4} 10 \mathrm{~kg} / \mathrm{ha}, \mathrm{T}_{8}-\mathrm{RPP}+$ $\mathrm{FeSO}_{4} 10 \mathrm{~kg} / \mathrm{ha}$ and $\mathrm{T}_{9}-\mathrm{RDF}+\mathrm{ZnSO}_{4} 10 \mathrm{~kg} / \mathrm{ha}+\mathrm{FeSo}_{4} 10$ $\mathrm{kg} / \mathrm{ha}$. Five plants from each plot were selected at random and recorded the observations. Plant height was measured at 30 and 60 days after sowing and at harvest, from the ground level to the base of the node on which the first fully opened leaf from the top and expressed in centimeter. The length of panicle was measured from the same sample of five randomly selected plants from each plot. It was measured from the neck to the tip of the ear heads and the average was computed. Grains from the harvested panicles of each plot of five plants were separated by threshing and weight was measured. The average weight of grains per panicle was computed. The net plots (leaving two borders on each side of the plot, 0.5 meters from each side of the plot) were harvested and sun dried for 3 days in the field and then the total biomass yield was recorded. After threshing, cleaning and drying, the grain yield was recorded and reported at 12 per cent moisture content. The straw yield was obtained by subtracting grain yield with total biomass yield and yield was expressed in $\mathrm{q} \mathrm{ha}^{-1}$.

\section{Results and Discussion}

Application of RDF alone to most crops is not sufficient to meet their demand. Soils deficient in micronutrients need external application and foliar application of NPK is also sometimes essential (table 1). Hence the study conducted revealed the following results. Yield components of finger millet as influenced by the different treatments. The integrated use of fertilizers was significantly influenced grain wight per panicle, grain yield and straw yield of foxtail millet. Appreciable increase in the grain yield of foxtail millet could be observed due to combination of organic and inorganic sources along with foliar nutrients. The grain and straw yields of finger millet as influenced by different treatments are presented in Table 3 and depicted in Fig.1. Soil application and foliar spray of fertilizers has resulted in significant yield differences among the treatments. The significantly higher grain weight per panicle $(2.80 \mathrm{~g})$, highest grain $\left(18.49 \mathrm{q} \mathrm{ha}^{-1}\right)$ and straw yield $\left(36.14 \mathrm{q} \mathrm{ha}^{-1}\right)$ in $\mathrm{T}_{4}$ treatment were recorded where application of RDF + foliar spray of 19:19:19 @ 1\% at flower initiation stage was done and it is at par with RDF+ 10 $\mathrm{kg} / \mathrm{ha} \mathrm{ZnSO}_{4}+10 \mathrm{~kg} / \mathrm{ha} \mathrm{FeSo}_{4}\left(16.67 \mathrm{q} \mathrm{ha}^{-1}, 34.39 \mathrm{q} \mathrm{ha}^{-1}\right.$ grain and straw yield, respectively). The lower yield (8.82 q $\mathrm{ha}^{-1}, 20 \mathrm{q} \mathrm{ha}^{-1}$ grain and straw yield, respectively) recorded in absolute control $\left(\mathrm{T}_{1}\right)$.

Soil and foliar application of macro and micro nutrients at critical stages of the crop were effectively absorbed and did translocation to the developing panicle thereby producing more panicle filling in foxtail millet. It could be attributed to the fact that higher availability of NPK during crop growth period might have improved the plant growth characters like plant height and weight of the grains which eventually led to higher yield. This is in agreement with the findings of Govindappa et al. (2009) ${ }^{[5]}$. Shivakumar et al. $(2011)^{[6]}$ and Ragupathi, (2017) ${ }^{[7]}$. Zinc and Iron are essential for several enzyme systems that regulate various metabolic activities in plants and also as essential component responsible for assimilation of nitrogen and also helps in formation of chlorophyll and played an important role in nitrogen metabolism. This might be due to the fact that zinc may serve as source of energy for synthesis of auxin which helps in elongation of stem (Singh and Verma, 1991) ${ }^{[8]}$.

The grain weight per panicle was also in similar trend as growth characters. The significantly highest grain weight per panicle (2.80) was recorded with RDF+ foliar spray of 19:19:19@1\% at flower initiation stage. However it was at par with RDF+ $10 \mathrm{~kg} / \mathrm{ha} \mathrm{ZnSO}_{4}+10 \mathrm{~kg} / \mathrm{ha} \mathrm{FeSo}$ (Table 3). This might be due to translocation of synthesized food materials from source to sink. This could be possible due to non limiting supplies of nutrient like $\mathrm{N}, \mathrm{P} \mathrm{K}, \mathrm{Zn}$ and $\mathrm{Fe}$ from the soil and fertilizers owing to their absorption. This is in line with the findings of Hasan et al. (2013) ${ }^{[9]}$. The biological yield and harvest index are also in similar trend as growth characters. The significantly highest indices $(54.63 \mathrm{~kg} / \mathrm{ha}$ and 51.16 , respectively) were recorded with RDF+ foliar spray of 19:19:19@1\% at flower initiation stage. However it was at par with RDF+ $10 \mathrm{~kg} / \mathrm{ha} \mathrm{ZnSO}_{4}+10 \mathrm{~kg} / \mathrm{ha} \mathrm{FeSo}$ (Fig.1 and Table 2).

Nutrient uptake by grain and straw of foxtail millet is observed that soil and foliar application of macro and micro nutrients at critical stages of the crop were effectively absorbed and did translocation to the developing parts of plant (Table 3). The significantly highest uptake of $\mathrm{N}$ by grain and straw (23.87 and $16.87 \mathrm{~kg} / \mathrm{ha}$ )) were recorded with $\mathrm{RDF}+$ foliar spray of 19:19:19 @ 1\% at flower initiation stage. However it was at par with RDF+ $10 \mathrm{~kg} / \mathrm{ha} \mathrm{ZnSO}_{4}+10 \mathrm{~kg} / \mathrm{ha}$ $\mathrm{FeSO}_{4}$ ) This is in agreement with the findings of Hasan et al.

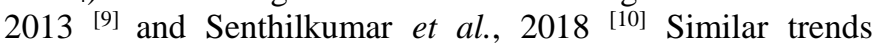
resulted in uptake of $\mathrm{P}(6.42$ and $2.73 \mathrm{~kg} / \mathrm{ha}), \mathrm{K}(9.67$ and $43.01 \mathrm{~kg} / \mathrm{ha}), \mathrm{Zn}(9.38$ and $31.95 \mathrm{~g} / \mathrm{ha})$ and $\mathrm{Fe}$ (4.47 and 39.35 $\mathrm{g} / \mathrm{ha}$ ) by grain and straw, respectively. 
Table 1: Initial soil properties of experimental plot at ICAR-KVK, Haveri

\begin{tabular}{|c|c|c|}
\hline Parameters & Value & Status \\
\hline $\mathrm{pH}(1: 2.5)$ & 6.56 & Neutral \\
\hline $\mathrm{EC}(\mathrm{dS} / \mathrm{m})$ & 0.40 & Normal \\
\hline $\mathrm{OC}(\%)$ & 0.42 & Low \\
\hline Available $\mathrm{N}\left(\mathrm{kg} \mathrm{ha}^{-1}\right)$ & 220 & Low \\
\hline Available $\mathrm{P}_{2} \mathrm{O}_{5}\left(\mathrm{~kg} \mathrm{ha}^{-1}\right)$ & 16.25 & Low \\
\hline Available $\mathrm{P}\left(\mathrm{kg} \mathrm{ha}^{-1}\right)$ & 7.40 & Low \\
\hline Available $\mathrm{K} 2 \mathrm{O}\left(\mathrm{kg} \mathrm{ha}^{-1}\right)$ & 162.0 & Medium \\
\hline Available $\mathrm{Zn}(\mathrm{ppm})$ & 0.45 & Deficient \\
\hline Available Fe $(\mathrm{ppm})$ & 2.15 & Deficient \\
\hline
\end{tabular}

Table 2: Response of Foxtail millet to nutrient management on yield components and yield (pooled of 2018 and 2019)

\begin{tabular}{|c|c|c|c|c|c|c|}
\hline Treatments & $\begin{array}{c}\begin{array}{c}\text { Panicle } \\
\text { length }(\mathrm{cm})\end{array} \\
\end{array}$ & \begin{tabular}{|c|} 
Grain weight \\
per panicle $(g)$
\end{tabular} & $\begin{array}{c}\text { Grain yield } \\
(\mathrm{q} / \mathrm{ha})\end{array}$ & $\begin{array}{c}\text { Straw yield } \\
(\mathbf{q} / \mathrm{ha})\end{array}$ & $\begin{array}{c}\text { Biological } \\
\text { yield (q/ha) }\end{array}$ & $\begin{array}{c}\text { Harvest } \\
\text { index }(\%)\end{array}$ \\
\hline $\mathrm{T}_{1}-$ Control & 9.98 & 1.43 & 8.82 & 20.00 & 28.82 & 44.10 \\
\hline $\mathrm{T}_{2}$-RPP (30:15:15 NPK kg ha-1 with FYM @ 6 t ha) & 14.60 & 2.08 & 14.30 & 27.63 & 41.93 & 51.76 \\
\hline $\mathrm{T}_{3}-\mathrm{RDF}+$ foliar spray of Urea @ 2\% at flower initiation stage & 16.54 & 2.08 & 14.94 & 28.60 & 43.54 & 52.24 \\
\hline $\begin{array}{c}\text { T4-RDF+ foliar spray of 19:19:19 @ 1\% at flower initiation } \\
\text { stage }\end{array}$ & 22.27 & 2.80 & 18.49 & 36.14 & 54.63 & 51.16 \\
\hline $\mathrm{T}_{5}$-Foliar spray of Urea @ 2\% flower initiation stage & 12.76 & 1.70 & 10.81 & 22.37 & 33.18 & 48.32 \\
\hline $\mathrm{T}_{6}$-Foliar spray of 19:19:19 @ 1\% at flower initiation stage & 12.42 & 1.86 & 11.64 & 22.71 & 34.35 & 51.25 \\
\hline T7-RDF+10 kg /ha Zn SO 4 & 17.16 & 2.44 & 16.50 & 31.71 & 48.21 & 52.03 \\
\hline $\mathrm{T}_{8}-\mathrm{RDF}+10 \mathrm{~kg} / \mathrm{ha} \mathrm{Fe} \mathrm{SO}_{4}$ & 15.55 & 2.01 & 14.26 & 30.03 & 44.29 & 47.49 \\
\hline $\mathrm{T}_{9}-\mathrm{RDF}+10 \mathrm{~kg} / \mathrm{ha} \mathrm{Zn} \mathrm{SO} \mathrm{S}_{4}+10 \mathrm{~kg} / \mathrm{ha} \mathrm{Fe} \mathrm{SO}_{4}$ & 19.41 & 2.41 & 16.97 & 34.39 & 51.36 & 49.35 \\
\hline S.Em \pm & 0.78 & 0.13 & 0.59 & 1.25 & 1.82 & 0.785 \\
\hline $\mathrm{CD}(\mathrm{P}=0.05)$ & 2.99 & 0.42 & 1.77 & 3.74 & 5.45 & 2.36 \\
\hline
\end{tabular}

Table 3: Effect of nutrient management on Nutrient uptake by Foxtail millet (pooled of 2018 and 2019)

\begin{tabular}{|c|c|c|c|c|c|}
\hline Treatments & $\begin{array}{c}\text { Total N } \\
\text { kg/ha }\end{array}$ & $\begin{array}{l}\text { Total P } \\
\text { (kg/ha) }\end{array}$ & $\begin{array}{l}\text { Total K } \\
\text { (kg/ha) }\end{array}$ & $\begin{array}{c}\text { Total Zn } \\
\text { (g/ha) }\end{array}$ & $\begin{array}{c}\text { Total } \\
\text { (Fe g/ha) }\end{array}$ \\
\hline $\mathrm{T}_{1}$ - Control & 17.67 & 3.53 & 22.65 & 26.28 & Mean \\
\hline $\mathrm{T}_{2}-\mathrm{RPP}$ & 30.45 & 6.23 & 38.58 & 33.99 & 32.63 \\
\hline $\mathrm{T}_{3}-\mathrm{RPP}+$ foliar spray of Urea @ 2\% at flower initiation stage & 31.15 & 6.77 & 40.15 & 33.96 & 37.18 \\
\hline $\mathrm{T}_{4}$-RPP + foliar spray of 19:19:19 @ 1\% at flower initiation stage & 40.67 & 9.14 & 52.67 & 41.32 & 38.07 \\
\hline $\mathrm{T}_{5}$-Foliar spray of Urea @ 2\% flower initiation stage & 20.70 & 4.45 & 27.19 & 27.45 & 43.82 \\
\hline $\mathrm{T}_{6}$-Foliar spray of 19:19:19@1\% at flower initiation stage & 22.34 & 4.84 & 28.60 & 29.24 & 33.53 \\
\hline T7-RPP+10 kg /ha ZnSO 4 & 33.62 & 7.49 & 44.54 & 37.63 & 34.05 \\
\hline $\mathrm{T}_{8}-\mathrm{RPP}+10 \mathrm{~kg} / \mathrm{ha} \mathrm{FeSO} 4$ & 29.67 & 6.66 & 41.66 & 33.41 & 39.97 \\
\hline $\mathrm{T}_{9}-\mathrm{RPP}+10 \mathrm{~kg} / \mathrm{ha} \mathrm{ZnSO} 4+10 \mathrm{~kg} / \mathrm{ha} \mathrm{FeSo} 4$ & 36.48 & 8.14 & 48.82 & 26.39 & 40.5 \\
\hline S.Em \pm & 2.93 & 0.71 & 4.26 & 4.59 & 44.43 \\
\hline $\mathrm{CD}$ & 8.12 & 2.10 & 12.64 & 13.63 & 7.84 \\
\hline
\end{tabular}

\section{Conclusion}

The present findings clearly indicated that soil and foliar application of nutrients increase the growth and yield of foxtail millet. It has the potential to improve the productivity of the crop grown in low fertile soils where fertilization is a constraint under conditions of low rainfall area. The growth and yield components were significantly higher with soil application of recommended dose of fertilizers with foliar application of 19:19:19 @ 1\% at flower initiation stage. Treatments receiving recommended package of practice with soil application of zinc and ferrous sulphate @ $10 \mathrm{~kg} / \mathrm{ha}$ were at par with each other but significantly superior over other treatments and control.

\section{References}

1. Fouly MM. Improving tolerance of faba beans during early growth stages to salinity through micronutrients foliar spray. Not. Sci. Biol. 2010; 16(2):98-102.

2. Amgai RB, Pantha S, Chhetri TB, Budhathoki SK, Khatiwada SP, Mudwari A. Variation on Agromorphological traits in Nepalese foxtail millet (Setaria italica (L) P Beauv): Agronomy Journal. 2013; 2(1):133138.
3. Devi PB, Vijayabharathi R, Sathyabama S, Malleshi NG, Priyadarisini VB. Health benefits of finger millet (Eleusine coracana L.) polyphenols and dietary fiber: a review. Journal of food science and technology, 2014; 51(6)1021-1040.

4. Bouis HE, Welch RM. Bio fortification- a sustainable agricultural strategy for reducing micronutrient malnutrition in the global south. Crop Sci. 2010; 50:1-13.

5. Govindappa M, Vishwanath A, Harsha K, Thimmegowda $\mathrm{P}$, Jnanesh A. Response of finger millet (Eleusine coracana L.) to organic and inorganic sources of nutrients under reined condition. J Crop. Weed. 2009; 5(2):291- 293.

6. Shivakumar B, Girish A, Gowda B, Kumar GV, Gowda AM, Thimmegowda M. Influence of Pongamia, Mahua and Neem cakes on finger millet productivity and soil fertility, Journal of Applied and Natural Science, 2011; 3(2):274-276.

7. Ragupathi KP, Sujatha K, Anand R, Sabir Ahamed A. Effect of organic foliar nutrition on growth and yield attributes of kodo Millet. American Int. J Res. Formal, App. Nat. Sci. 2017; 16(1):23-27. 
8. Singh SS, Verma SK. Influence of potassium zinc and boron on growth and yield of tomato (L. esculcntum Mill). Veg. Sci. 1991; 18(2):122-129.

9. Hasan M, Rashid M, Rahman Q, Al-Mamun M. Influence of seed rates and levels of NPK fertilizers on dry matter accumulations and yield performance of foxtail millet (Setaria italica L. Beauv.). Bangladesh Journal of Agricultural Research, 2013; 38(4):689-704.

10. Senthilkumar N, Poonkodi P, Prabhu N. Response of Pearl Millet to Integrated Use of Organics and Fertilizers. Journal of Eco biotechnology, 2018; 17(2):01-04. 